\title{
QUALITY AND ANTIOXIDANT PROPERTIES OF WHOLE AND FRESH CUT 'CHERRY' PEPPERS DURING STORAGE AT $10^{\circ} \mathrm{C}$
}

\author{
Karina. R. Avalos Llano(1); Sonia C. SGROPPO(1) y Alicia R. Chaves (2)
}

RESUMEN: Se estudiaron los cambios de calidad y propiedades antioxidantes de pimientos (Capsicum annuum, L. Cv 'Cherry') enteros y descorazonados, conservados a $10^{\circ} \mathrm{C}$ durante 10 días en bandejas PET cubiertas con film de PVC. Durante ese periodo se evaluó la apariencia general, color, actividad respiratoria, contenido de azúcares totales y firmeza de los frutos, así como también las modificaciones en el contenido de carotenoides y fenoles totales, ácido ascórbico y capacidad antioxidante. Inmediatamente después del corte y a lo largo del almacenamiento, se notó un incremento de la actividad respiratoria. El color superficial prácticamente no varió y no se observaron diferencias significativas entre frutos enteros y descorazonados en la firmeza, contenido de azúcares totales y carotenoides. En pimientos enteros y descorazonados los contenidos de fenoles totales, ácido ascórbico y capacidad antioxidante, no variaron notoriamente durante el almacenamiento. Sin embargo, al finalizar la experiencia (10 días), los frutos enteros presentaron una apariencia general buena y mayor calidad global que los pimientos descorazonados. L os resultados sugieren que el pimiento Cherry podría comercializarse como pimiento fresco cortado en la forma descorazonada, aunque debería almacenarse por sólo 6-7 días a $10^{\circ} \mathrm{C}$.

A bstract: Changes on quality and antioxidant properties of whole and fresh cut (without the core) peppers (Capsicum annuum, L. CV. 'Cherry'), stored for 10 days at 10ㄷ in PET trays covered with PVC film were studied. During the storage their general appearance, fungal decay, color, respiration rate, sugar content and firmness were evaluated. Changes on carotenoids, total phenols, ascorbic acid and antioxidant capacity were also studied. Immediately after cutting and throughout the storage, an increase in respiration rate was found. No differences in color evolution were observed during storage between whole and fresh cut fruits. There were no differences in firmness, total sugars and carotenoids between whole and cut fruits either. Total phenols, ascorbic acid and antioxidant capacity did not change largely in both intact and without core peppers during the experiences. However at the end of the storage period (10 days), whole pepper fruit displayed good general appearance and overall higher quality than de-cored fruit. Results suggest that Cherry peppers could be marketed as fresh-cut peppers in the type of without core fruits, although they would be only stored for 6-7 days at $10^{\circ} \mathrm{C}$.

Palabras claves: Pimientos Cherry; capacidad antioxidante; fenoles totales; ácido ascórbico Key words: Cherry peppers, antioxidant capacity, total phenols, ascorbic acid

\section{INTRODUCCIÓN}

Cherry peppers (Capsicum annuum, L. Cv. 'Cherry') are small (diameter of 26 to $32 \mathrm{~mm}$ ), fruits with bright red color and sweet taste. While their size and appearance might be appealing, they present a large number of seeds making tedious home prepara-

(1) Laboratorio de Tecnología Química, Facultad de Ciencias Exactas y Naturales y Agrimensura, UNNE, Av. Libertad 5450, (3400) Corrientes, Argentina. E-mail: kavalosllano@yahoo.com.ar; scsgroppo@gigared.com

(2) Centro de Investigación y Desarrollo en Criotecnología de Alimentos (CIDCA), UNLPCONICET, 47 y 116, (1900) La Plata, Argentina. 
tion operations. Fresh-cut products are lightly processed fruits and vegetables with increased functionality maintaining most properties of fresh products (Salunkhe et al., 1991). However, in general fresh cut products deteriorate rapidly and show reduced shelf-life compared to whole fruits and vegetables (Conesa et al., 2007b). During their preparation there are different steps as selection, washing, cutting, seed separation, draining and packaging, which have a great influence in the organoleptic, nutritional and microbiological characteristics of the final product. These vegetables can show symptoms of deterioration as dehydration, color and texture changes, loss juice and/or microbial growth during the storage. In order to minimize these effects and to achieve a high quality product, it is crucial to select properly the variety and maturity of the raw material, process, packaging and storage conditions (W atada et al., 1999).

Peppers (Capsicum annuum, L.) are a good source of bioactive compounds (Howard et al., 2000). Ascorbic acid, phenolic and carotenoid compounds contribute to the nutritional value and to the health-promoting properties of sweet peppers (Raffo et al., 2007).

There are no studies about the postharvest behavior of Cherry peppers and less of the evolution of physical and compositional parameters of lightly processed-Cherry peppers during refrigerated storage. The purpose of this paper is to evaluate the changes on quality parameters and antioxidant properties of whole and cut 'Cherry' peppers during storage at $10^{\circ} \mathrm{C}$.

\section{MATERIALS AND METHODS}

Plant material. Cherry peppers (C. annuum, L. CV. 'Cherry') produced in Corrientes city (A rgentina), having 95-100\% red color, were used for this study. Fruit free of damage and uniform size (weight: $10 \pm 1.1 \mathrm{~g}$ ) were selected.

Processing and storage. Peppers were carried to the lab within 24 hours of being harvested. Fruits were washed with chlorinated water $(100 \mathrm{mg} / \mathrm{L}, 20$ seconds) and then divided into three lots. Cores of fruits from one of the lots were removed, a small area of tissue was extracted around of their peduncle with a $13 \mathrm{~mm}$ diameter core-borer and their seeds and placental tissue were eliminated (without core). Peppers from the second group were cut into halves (from which seeds were also removed), and those from the third lot were not cut. Fruits from the three lots were packaged in crystalline PET trays and covered with PV C film. Twelve trays for each treatment were prepared, containing each one approximately $70 \mathrm{~g}$ (7 fruits). The trays were stored at $10^{\circ} \mathrm{C}$ for 10 days and were sampled at day 0 and during storage ( 3 trays separated by type of cut and storage time). Samples were immediately processed or otherwise frozen at $-20 \stackrel{\circ}{C}$ until analysis. The complete experiment was repeated three times. Since results from the different experiments showed a similar trend data from the first one is shown. M easurements determinations were done in triplicate on vegetal material corresponding to different combinations type of cut/storage time.

Sensory quality. A subjective evaluation of the whole or cut- fruits were realized, in a storage time determined, examining visually their general appearance (taking into 
account color, brightness, firmness, dehydration). The percentage of fruits which presented macroscopic fungal growth was visually evaluated.

In order to evaluate the general appearance, the following scale was used: 1 = very good or fresh appearance, $2=$ good, $3=$ fair, $4=$ poor. The index of general appearance (I) was calculated for a determined time, trough this formula:

$$
I=\frac{1 n+2 n+3 n+4 n}{N}
$$

where:

$\mathrm{n}$ : number of fruits or pieces in that category.

$\mathrm{N}$ : total number of examined fruits or pieces.

It was considered that fruits lost market quality when I >2.

Color. Fruit color was evaluated with a colorimeter (M inolta, M odel CR-300), by measuring the $L^{*}, a^{*}$ and $b^{*}$ parameters in three zones of each fruit. Ten fruits from each type of cut and storage time were analyzed.

Respiration rate. Ten fruits were placed in a hermetic jar, the $\mathrm{CO}_{2}$ produced by fruits was determined, during an hour, realizing the test every 5 minutes, using a sensor IR (A Inor Compu Flow ${ }^{\circledR}$ M odel 8650). From the obtained straight line the $\mathrm{CO} 2$ production rate was calculated. Results were expressed as $\mu \mathrm{L} \mathrm{CO}_{2} / \mathrm{g} \mathrm{h}$.

Total sugars. Five grams of tissue was ground with $30 \mathrm{~mL}$ of ethanol. The mixture was homogenized for $15 \mathrm{~min}$ in a homogenizer stirrer (GLAS-COL, M odel 099C K 4424, Terre Huate, IN, USA ) and then centrifuged at $5000 \times \mathrm{g}$ for $10 \mathrm{~min}$. The supernatant was utilized to determine total sugar content by the anthrone method (Southgate, 1976). The absorbance was measured at $620 \mathrm{~nm}$. A calibration curve was prepared by using glucose as a standard. Results were expressed as grams of glucose per 100 grams of fresh weight (f.w.).

Firmness. The maximum force of penetration was recorded. Firmness was measured by using a Texture A nalyzer (TA -X T2i) by compression tests. Each fruit piece was penetrated $3 \mathrm{~mm}$ with a $3 \mathrm{~mm}$ diameter flat probe at a rate of $0.5 \mathrm{~mm} / \mathrm{s}$ on the equatorial zone. Fifteen fruits of similar size were used. Eight determinations were done in each fruit.

Total carotenoids. Carotenoids determination was performed by visible spectrophotometry. Five grams of tissue was ground in $35 \mathrm{~mL}$ of acetone and homogenized for $15 \mathrm{~min}$. The mixture was vacuum filtered, washing the residue with acetone until a complete disappearance of color in the tissue. The volume of the acetonic extract was measured. A fterwards, $25 \mathrm{~mL}$ of it were transferred to a separating funnel and then the carotenoids were extracted with $25 \mathrm{~mL}$ of petroleum ether 35-60 bp. The volume of the ethereal extract was measured and its absorbance was determined at $450 \mathrm{~nm}$. The extinction coefficient was $2.5 \times 10^{5} \mathrm{~mL} / \mathrm{g} \mathrm{cm}$ (Davies et al., 1970). Results were expressed as micrograms of $\beta$-carotene per gram of fresh weight.

Total phenols. Five grams of tissue was ground in $30 \mathrm{~mL}$ of ethanol. The mixture was homogenized for $15 \mathrm{~min}$ in a homogenizer stirrer (GLAS-COL, M odel 099C K 4424, Terre Huate, IN, USA) and then centrifuged at $5000 \times \mathrm{g}$ for $10 \mathrm{~min}$. Total phenolic content in the supernatant was determined using Folin-Ciocalteau reagent (Singleton et al., 
1999). The absorbance was measured at $760 \mathrm{~nm}$ and the total phenols content was calculated using $1.13 \times 10^{-3} \mathrm{~mol} / \mathrm{L}$ clorogenic acid as standard. Results were expressed in milligrams of clorogenic acid per gram of fresh weight.

Ascorbic acid content. The content in ascorbic acid of peppers was assessed by HPLC using a Shimadzu LC-10A T chromatograph, with a UV -visible detector Shimadzu SPD-10A. Ten grams of sample were homogenized in $0.05 \mathrm{~mol} / \mathrm{L} \mathrm{H}_{3} \mathrm{PO}_{4}$ (NisperosCarriedo et al., 1992). The mixture was filtered and centrifuged at $10000 \times \mathrm{g}$ for $20 \mathrm{~min}$ at $4 \stackrel{\circ}{ } \mathrm{C}$. The resultant supernatant was filtered prior to the injection into the chromatograph, through nylon membranes of $0.45 \mu \mathrm{m}$. The mobile phase was methanol: $\mathrm{H}_{2} \mathrm{O}$ (30:70), $\mathrm{pH}: 2.8$ (with $0.05 \mathrm{~mol} / \mathrm{L} \mathrm{H}_{3} \mathrm{PO}_{4}$ ), at a flow rate of $1 \mathrm{~mL} / \mathrm{min}$ and the chromatographic column used was Supelcosil LC $18.5 \mu \mathrm{m} \times 250 \mathrm{~mm}$. A bsorbance at $260 \mathrm{~nm}$ was determined. For identification and quantification a $1.53 \times 10^{-3} \mathrm{~mol} / \mathrm{L}$ standard ascorbic acid solution was used. Results were expressed in milligrams of ascorbic acid per 100 grams of fresh weight.

Antioxidant capacity. In order to determine the antioxidant activity of fruits the radical chromogen 2,2-diphenyl-1-picrylhydrazyl (DPPH ${ }^{\bullet}$ ) in methanol solution was used (B rand-W illiams et al., 1995). Five grams of tissue were ground in $30 \mathrm{~mL}$ of ethanol by using a homogenizer stirrer (GLA S-COL, M odel 099C K 4424, Terre Huate, IN, USA). The extract was centrifuged at $5000 \mathrm{xg}$ for $10 \mathrm{~min}$. Different aliquots of supernatant $(0-600 \mu \mathrm{L})$ were added to test tubes containing $3.4 \mathrm{~mL}$ of $7.61 \times 10^{-5} \mathrm{~mol} / \mathrm{L} \mathrm{DPPH}{ }^{\bullet}$ in methanol prepared daily (final volume of reaction: $4 \mathrm{~mL}$ ). A bsorbance at $517 \mathrm{~nm}$ was measured with a spectrophotometer M etrolab 1700 at different times until the reaction reached a plateau. The \% of remaining $\mathrm{DPPH}^{\bullet}$ against the volume of extract was then plotted to obtain the amount of extract necessary to decrease the initial DPPH ${ }^{\bullet}$ concentration by $50 \%$, which was defined as $\mathrm{EC}_{50}$. Results were expressed in milligram of fresh weight.

Statistical analysis. Experiments were performed according to a factorial design. The factors were the type of cut and the storage time. Data were statistically analyzed by the analysis of variance (A NOVA), and means were compared by the test LSD at a significance level of 0.05 (InfoStat, 2002).

\section{RESULTS AND DISCUSSION}

Fig. 1 shows the index of general appearance $(\mathrm{I})$ during storage at $10^{\circ} \mathrm{C}$. The general aspect of whole peppers relatively unchanged during storage, reaching a good general appearance $(I=2)$ after 10 days at $10^{\circ} \mathrm{C}$. In contrast the cut fruits showed a continuous and more rapid decline in quality, reaching an index between good and fair $(\mathrm{I}=2.5$ 2.7) after 10 days. However, the cut peppers were still marketable at 6 days of storage. 


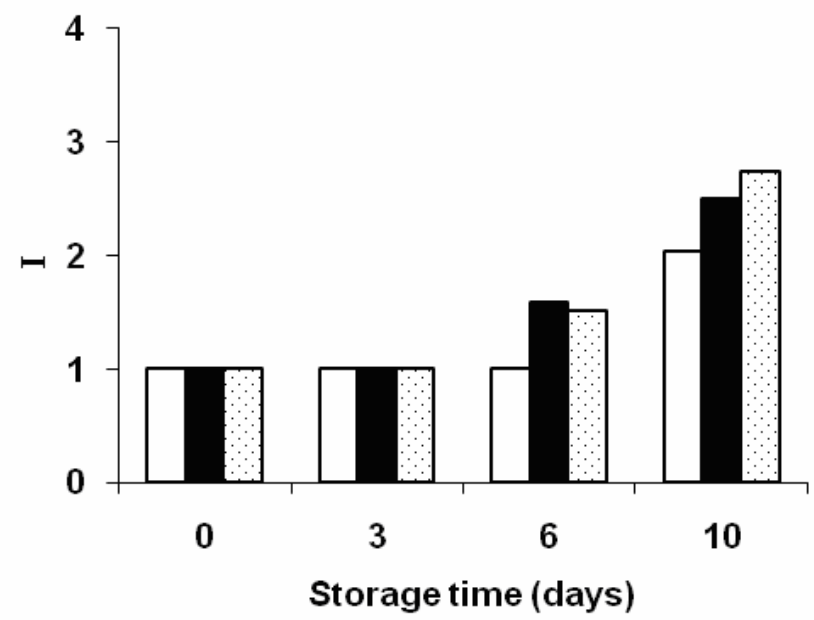

Fig. 1: Index of general appearance (I) in whole ( $\square$ ), de-cored ( $\mathbf{})$ and halved ( $)$ Cherry peppers stored during 10 days at $10^{\circ} \mathrm{C}$. $\left(\mathrm{LSD}_{0.05}=1.2\right)$.
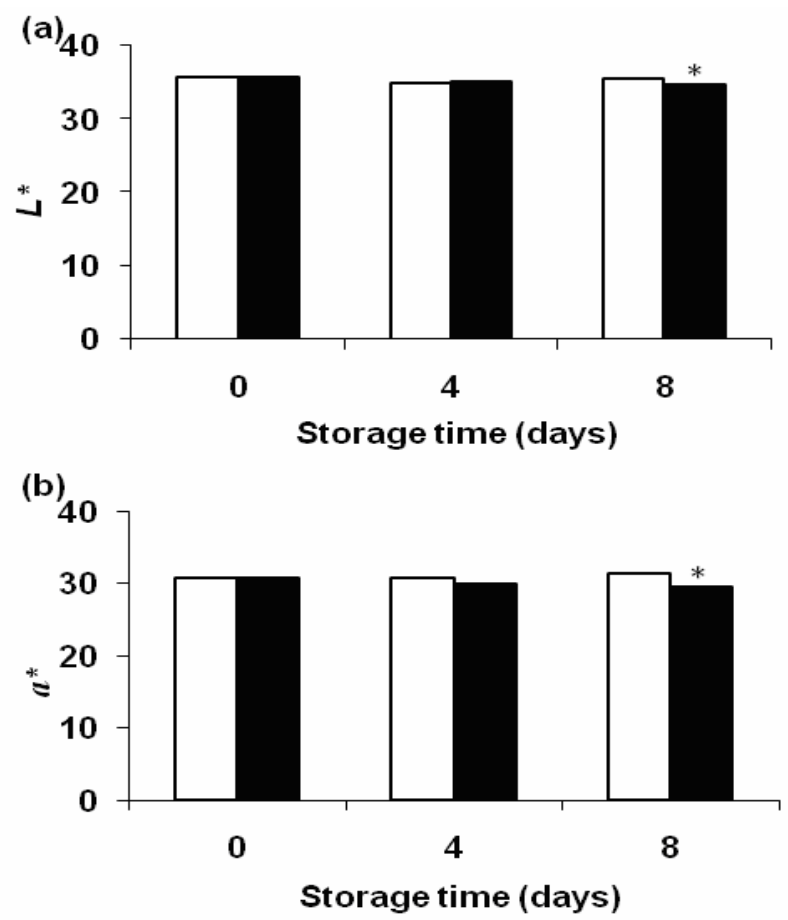

Fig. 2: Changes in (a) lightness $\left(L^{*}\right)$ and (b) $a^{*}$ value of whole ( $\square$ ) and de-cored (a) fruit stored at $10^{\circ} \mathrm{C}$. $*$ Value significantly different from that corresponding to whole peppers $\left(\operatorname{LSD}_{L^{*}}=0.46\right.$; $\left.\operatorname{LSD}_{a^{*}}=1.14\right)$. 
In the case of decay, higher incidence was observed in cut halves fruits after 10 days at $10^{\circ} \mathrm{C}$ (approximately $50 \%$ of fruits) (data not shown). Since the halved peppers were the most deteriorated, the following experiences were performed with only a type of cut (without core fruits).

Lightness parameter $\left(L^{*}\right)$ presented an initial value of $35.6 \pm 1.0$ (Fig. 2a), which was close to the reported for peppers Cv. Zafiro (90\% red) (V icente et al., 2005). No differences in fruit lightness $\left(L^{*}\right)$ were found between intact and without core fruits until the eight day of storage at $10^{\circ} \mathrm{C}$ when without core peppers showed a value of $L^{*} 2.5 \%$ lower than that of control fruits. The parameter $a^{*}$ showed a similar evolution (Fig. 2b), for both treatments. Concerning parameter $b^{*}$, there were no differences between control and cut fruits during storage (data not shown). No variation in superficial color parameters during storage could be due to the fact that the fruits were already at advanced ripening stage.
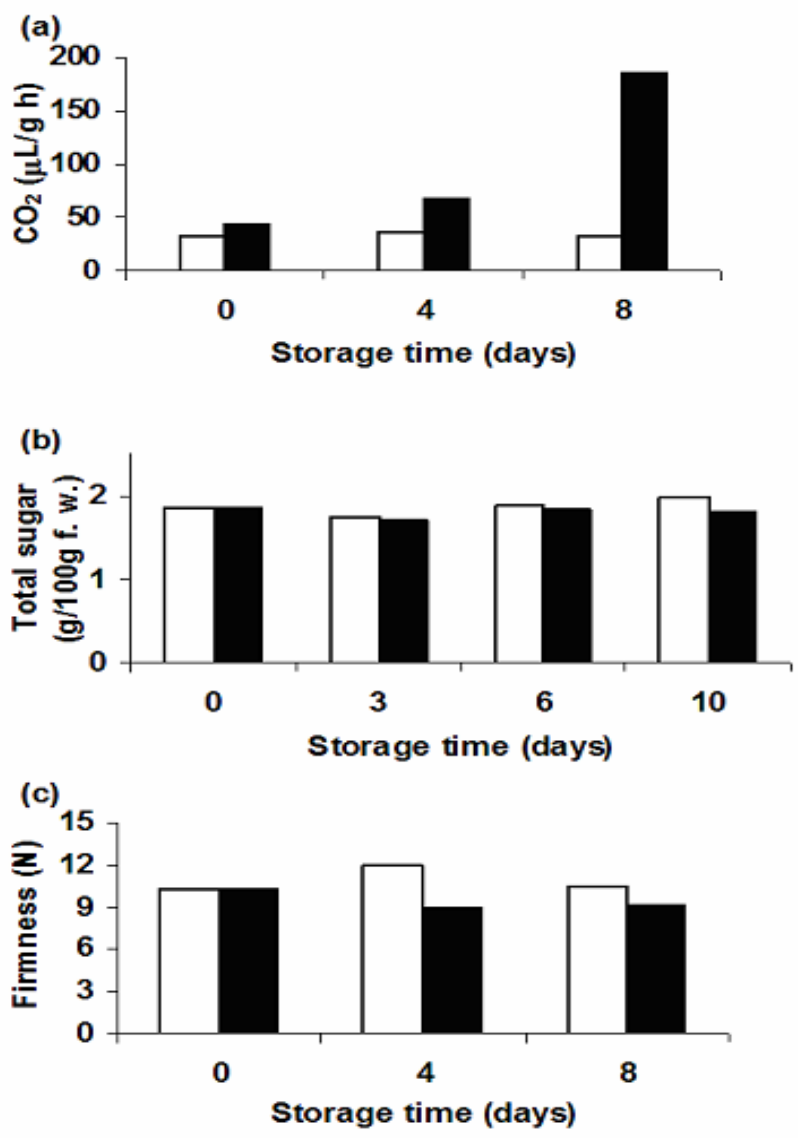

Fig. 3: Changes in (a) respiration rate, (b) sugar content and (c) firmness of whole ( $\square$ ) and decored $(\square)$ fruit stored at $10^{\circ} \mathrm{C} .\left(\mathrm{LSD}_{\text {respiration rate }}=28.99 ; \mathrm{LSD}_{\text {sugar content }}=0.1 ; \mathrm{LSD}_{\text {firmness }}=1.16\right)$. 
Peppers are fruits which generally show a low respiration rate, (B arth et al., 2004). Initial levels of $\mathrm{CO}_{2}$ production in whole Cherry peppers were $32.26 \pm 2.07 \mu \mathrm{L} / \mathrm{g} \mathrm{h}$, and did not change significantly during storage at $10^{\circ} \mathrm{C}$ (Fig. 3a). These results were similar those reported by other authors for other pepper varieties (G onzál ez-A guilar et al., 1999).

One of the changes promoted as response to the wound during the preparation of fresh-cut vegetables is the respiration increase (B arth et al., 2004; B eaulieu et al., 2003). Respiration rate increased to value of $44.84 \pm 2.54 \mu \mathrm{L} / \mathrm{g} \mathrm{h}$ immediately after the cut, presenting a continuous increment throughout the storage (Fig. 3a). At the end of the storage period, the $\mathrm{CO}_{2}$ production of cut peppers increased about 4 fold, which may be attributed to the deterioration observed. A similar behavior was informed for green chilly peppers stored for 6 days at $10{ }^{\circ} \mathrm{C}$ ( $\mathrm{K}$ ang et al.,1997), and for diced green and red bell peppers (El-B assuoni et al.,1994).

The main sugars influencing peppers fruit taste are glucose, fructose and to a lower extent sucrose. Initial values of total sugars were $1.87 \pm 0.08 \mathrm{~g}$ glucose $/ 100 \mathrm{~g}$ fresh weight. During storage sugar content remained practically invariable. Pepper processing did not cause variations in total sugar contents (Fig. 3b). Similarly, Conesa et al. (2007a) did not find changes in total sugars in red peppers cut in cubes after 10 days at $5^{\circ} \mathrm{C}$. While, Raffo et al. (2007) informed that glucose and fructose of red peppers were constant during 21 days at $7.5^{\circ} \mathrm{C}$. Contrarily, R affo et al. (2008) observed a significant increase for sliced red peppers stored for 9 days at $8{ }^{\circ} \mathrm{C}$, due to the effect of concentration related to the water loss. In our experiences there was only a slight dehydration.

Tissue softening is a very serious problem with fresh-cut fruit products that can limit shelf-life. Vicente et al. (2005) reported a reduction in Zafiro peppers upon storage for 12 days at $10^{\circ} \mathrm{C}$. González A guilar et al. (2004) found a continuous decrease of firmness in green cut peppers, stored in M AP during 14 days at $10^{\circ} \mathrm{C}$. The authors related this decrease to fungal growth. Toivonen et al. (2004) found a decrease in the firmness of green cut peppers stored in modified atmosphere at $10^{\circ} \mathrm{C}$ for 10 days. However in the present study the firmness virtually did not change in whole fruits during storage at $10^{\circ} \mathrm{C}$. In contrast, firmness decreased slightly in de-cored peppers, reaching values $13 \%$ lower than the whole fruits ones at the end of storage (Fig. 3c) which could be related to the slight dehydration and damage observed.

The Cherry peppers presented initially total carotenoid content expressed as $\beta$-carotene of $276 \pm 9 \mu \mathrm{g} / \mathrm{g}$ fresh weight. At the end of the storage at $10^{\circ} \mathrm{C}$, a slight increase of $8 \%$ relative to the initial carotenoids content was detected in whole fruits (Fig. 4). Even so, this increase was not reflected in superficial color evolution. Vicente et al. (2005) found an increase of carotenoids in Cv. Zafiro 90\% red whole peppers at day 12 of storage at $10^{\circ} \mathrm{C}$. 


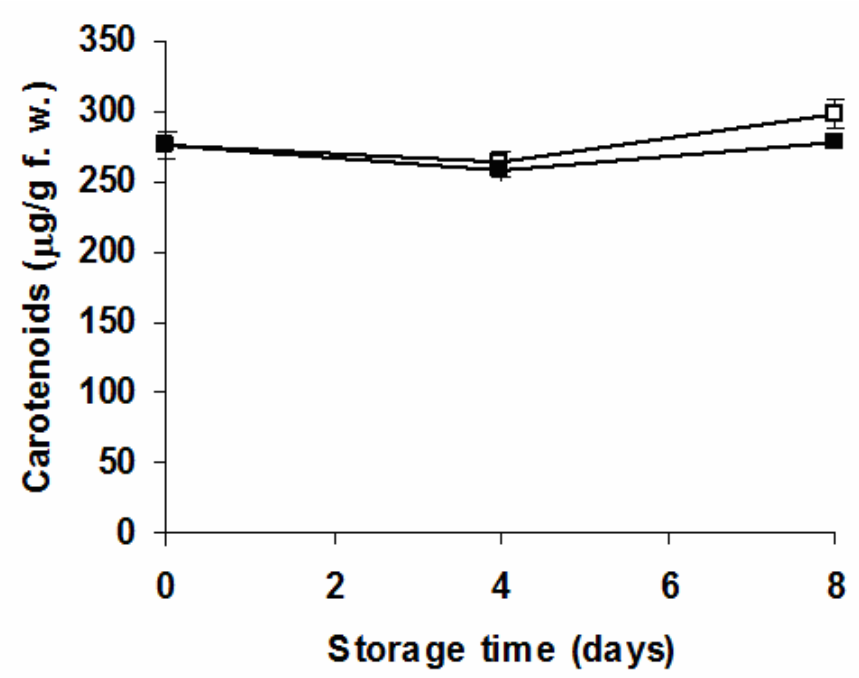

Fig. 4: Changes in (a) carotenoid content ot whole ( $\square$ ) and de-cored (匹) truit during storage at $10^{\circ} \mathrm{C}$. Bars represent standard error of the mean.

No significant differences in pigments content were observed between control and without core fruits (Fig. 4). In other assays, fruits with initial carotenoids content of 204 $\pm 4 \mu \mathrm{g} \beta$-carotene/g fresh weight showed an increase of $40 \%$ during the storage of whole peppers similar to the evolution of without core fruits.

Total phenols initial level was $3.90 \pm 0.20 \mathrm{mg}$ clorogenic acid/g fresh weight. Total phenols values did not change significantly during storage at $10^{\circ} \mathrm{C}$ for both assays conditions (whole and without core fruits) (Fig. 5a). Similar results were reported in cut red peppers Cv. 'Festos' (Sgroppo et al., 2005), whereas a decrease in total phenols level in sliced green peppers stored at $7{ }^{\circ} \mathrm{C}$ for 10 days of storage were observed by Toivonen et al. (2004).

The initial ascorbic acid content was $62.7 \pm 1.7 \mathrm{mg} / 100 \mathrm{~g}$ fresh weight and it remained relatively constant in whole fruits during the storage period (Fig. 5b). Hussein et al. (2000) did not find changes in the content of vitamin $C$ in green peppers stored at 4ㅇ. Otherwise, Toor et al. (2006) found that a relative stability of ascorbic acid content in stored tomatoes at $7^{\circ} \mathrm{C}$ could be related to the acidity and the presence of phenols and flavonoids in tissue. On the other hand, R affo et al. (2007) informed a slight increase of ascorbic acid content in whole red peppers stored for 21 days at 7.5ㅇ. 

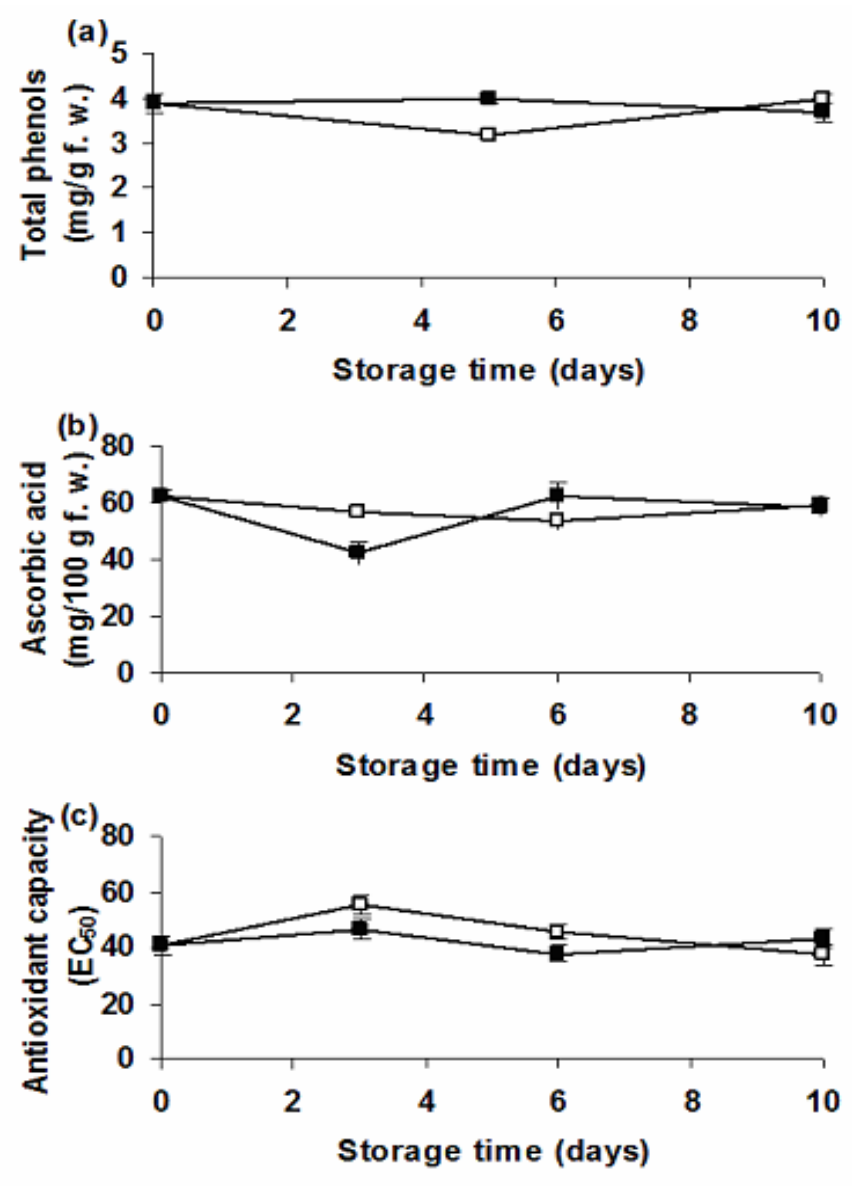

Fig. 5: Changes in (a) total phenols, (b) ascorbic acid content and (c) antioxidant capacity of whole ( $\square$ ) and de-cored ( $\square$ ) fruit during storage at $10^{\circ} \mathrm{C}$. Bars represent standard error of the mean.

The content of ascorbic acid remained almost constant in without core Cherry peppers during storage at $10^{\circ} \mathrm{C}$. In addition, no differences were observed between control and de-cored fruits (Fig. 5b). González-A guilar et al. (2004) found that ascorbic acid content of cut green peppers ( $\mathrm{Cv}$. 'Wonder') did not change during the storage at $10^{\circ} \mathrm{C}$, while Raffo et al. (2008) reported an increment in ascorbic acid content in sliced red peppers stored at $8^{\circ} \mathrm{C}$, relating those changes to the concentration effect associated to water loss. On the other hand, Hussein et al. (2000) informed a vitamin C content decreased in sliced green peppers stored at $4^{\circ} \mathrm{C}$.

A ntioxidant capacity expressed as $\mathrm{EC}_{50}$ was determined using the radical chromogen $\mathrm{DPPH}^{\bullet}$. The initial $\mathrm{EC}_{50}$ was $41.2 \pm 3.6 \mathrm{mg}$ fresh weight. Higher values of $\mathrm{EC}_{50}$ represent low values of antioxidant activity. Whole fruits showed an $\mathrm{EC}_{50}$ increase of $35 \%$ at the third day of storage at $10^{\circ} \mathrm{C}$, and then it decreased until the end of storage reaching a no different significant value compared to the initial one at day 10 (Fig. 5c.). 
V icente et al. (2005) in another variety of whole sweet peppers (cv. 'Zafiro'), did not observe modifications in the antioxidant capacity at day 12 of storage at $10{ }^{\circ} \mathrm{C}$.

$\mathrm{EC}_{50}$ in without core Cherry peppers relatively unchanged during the experience. (Fig. 5c). A antioxidant activity decrease more than $20 \%$ of the initial level was detected in diced red peppers CV. 'M argarita' at day 7 of storage at 11으 (Sgroppo et al., 2004).

A ccording to the obtained results, it is evident that no changes relative to the initial antioxidant activity were observed in both whole and without core peppers at the end of storage. L ana et al. (2006) did not find differences in the total antioxidant activity, measured using a lipid peroxidation inhibition assay, between whole and sliced tomatoes during the refrigerated storage. A lthough, Odriozola-Serrano et al. (2008) informed an antioxidant capacity decrease in fresh cut tomatoes during the storage.

\section{CONCLUSIONS}

W hole Cherry peppers maintained their quality during storage for 10 days at $10^{\circ} \mathrm{C}$, presenting slight variation of chemical-physical parameters analyzed. However, de-cored fruits conserved their quality very well for 6-7 days of storage at $10^{\circ} \mathrm{C}$ without showing noticeable changes in the carotenoid content, total phenols, ascorbic acid and antioxidant capacity. Due to the scarce variation in the antioxidant characteristics, light processing did not decrease the nutritional quality of the product. Results suggest that Cherry peppers could be marketed as fresh-cut Cherry peppers in the type of without core fruits. Further complementary treatment to refrigeration might be evaluated in fresh cut peppers intended for storage periods longer than 6-7 days.

\section{ACKNOWLEDGEMENT}

This work is part of the project PI 102-07 "Cambios Nutricionales y Sensoriales en Productos Vegetales Mínimamente Procesados de la Región del NEA" financed by SGCYT-UNNE, A rgentina. KRALL wishes to thank the CONICET and SGCYT-UNNE for granting her a doctoral scholarship. We also thank to M r. P. Hermosilla for supplying plant material.

\section{REFERENCES}

Barth, M.M.; H. Zhuang and M.E. Saltveit, 2004. Fresh-cut Vegetables. Available from: www.usna.usda.gov/hb66/147freshcutvegetables.pdf. A ccessed October 2007.

BeAulieu, J.C. and J.R. GoRnY, 2003. Fresh-cut fruits. Available from: www.ba.ars.usda.gov/hb66/ 146freshcutfruits.pdf. A ccessed September 2007.

BRAND-Williams, W.; M .E. CUVElier and C. Berset, 1995. U se of a free radical method to evaluate antioxidant activity. Lebensmittel-Wissenschaft und-Technologie, 28: 25-30. 
Conesa, A.; F. A rtés-Hernández; S. Geysen; B. Nicolaï and F. Artés, 2007a. High oxygen combined with high carbon dioxide improves microbial and sensory quality of fresh-cut peppers. Postharvest Biology and Technology, 43: 230-237.

Conesa, A.; B.E., Verlinden; F. A RTÉs-Hernández; B. Nicolaï and F. A RTÉs, 2007b. Respiration rates of fresh-cut bell peppers under superatmospheric and low oxygen with or without high carbon dioxide. Postharvest Biology and Technology, 45: 81-88.

DAVIES, B.H.; S. M ATHEWS and J.T.O. KIRK, 1970. The nature and biosynthesis of the carotenoids of different colour varieties of Capsicum annuum. Phytochemistry, 9: 797-805.

EL-BASSUONI, R. and M. CANTWELL, 1994. Low temperatures and controlled atmospheres maintain quality of fresh cut bell pepper. HortScience, 29: 448.

GonzÁlez A GUILAR, G.A.; R. CRUZ and R. BAEZ, 1999. Storage quality of bell peppers pretreated with hot water and polyethylene packaging. J ournal of F ood Q uality, 22: 287-299.

González Aguilar, G.A.; J.F. Ayala-Zavala; S. Ruiz-Cruz; E.M. Acedo-Félix and E. Díaz-Cinco, 2004. Effect of temperature and modified atmosphere packaging on overall quality of fresh-cut bell peppers. Lebensmittel-Wissenschaft und-Technologie, 37(8): 817-826.

HOWARD, L.R.; S.T. TALCOTT; C.H. BRENES and B. VILLALON, 2000. Changes in phytochemical and antioxidant activity of selected pepper cultivars (Capsicum species) as influenced by maturity. J ournal of Agricultural and Food Chemistry, 48: 1713-1720.

Hussein, A.; J.A. Odumeru, T. Ayanbadejo; H. Faulkner; W.B. Mcnab; H. Hager and L. Szijarto, 2000. Effects of processing and packaging on vitamin $C$ and $\beta$-carotene content of ready-to-use (RTU) vegetables. F ood Research International, 33: 131-136.

INFOSTAT/EstUdIANTIL, 2002.Versión 2.0. Universidad Nacional de Córdoba. Estadística y Diseño. FCA.

KANG, J.S. and D.S. LEE, 1997. Susceptibility of minimally processed green pepper and cucumber to chilling injury as observed by apparent respiration rate. International J ournal of F ood Science and Technology, 32: 421-426.

LANA, M.M .and L.M.M. TIJSKENS, 2006. Effects of cutting and maturity on antioxidant activity of fresh-cut tomatoes. F ood Chemistry, 97(2): 203-211.

Nisperos-CarRiedo, M .O .; B.S. Busling and P.E. Shaw, 1992. Simultaneous detection of dehydroascorbic, ascorbic, and some organic acids in fruits and vegetables by HPLC. J ournal of Agricultural and F ood Chemistry, 40: 1127-1130.

Odriozola-Serrano, I.; R. Soliva-Fortuny and O. Martín-Belloso, 2008. Effect of minimal processing on bioactive compounds and color attributes of fresh-cut tomatoes. Lebensmittel-Wissenschaft undTechnologie, 41: 217-226.

RafFo, A.; I. Baiamonte; N. NARdo and F. PaOletti, 2007. Internal quality and antioxidants content of cold-stored red sweet peppers as affected by polyethylene bag packaging and hot water treatment. European F ood Research and Technology, 225: 395-405.

RAFFO, A.; I. BAIAM ONTE and F. PAOLETTI, 2008. Changes in antioxidants and taste-related compounds content during cold storage of fresh-cut red sweet peppers. European F ood Research and Technology, 226: 1167-1174.

SALUnKhe, D. and B. Desal, 1991. Postharvest Biotechnology of V egetables. Boca Raton: CRC Press.

SGROPPO, S.C.and G.M. M ONTIEL, 2004. Estado actual del mercado de frutos y vegetales frescos cortados en A rgentina. Pp. 61-69. In G. González-A guilar, \& F. Cuamea-N avarro (Eds.): CYTED, Estado actual del mercado de frutos y vegetales cortados en Iberoamérica. M éxico. 
Sgroppo, S.C.; M.V. Pereira and K.R. Avalos Llano, 2005. Efectos de la aplicación de luz UV -C en pimientos frescos cortados. Pp. 59-64. In G. González-A guilar, \& F. Cuamea- Navarro (Eds.): CYTED, Vegetales frescos cortados. M éxico.

Singleton, V.L.; R. ORthofer and R.M. Lamuela-Raventós, 1999. A nalysis of total phenols and other oxidation substrates and antioxidants by means of Folin-Ciocalteau reagent. M ethods in Enzymology, 299: 152-178.

Southgate, D.A.T., 1976. D eter mination of food carbohydrates. A pplied Science Publ., L ondon. 108 p.

TOIVONEN, P.M.A. and S. STAN, 2004. The effect of washing on physicochemical changes in packaged, sliced green peppers. International J ournal of F ood Science and Technology, 39: 43-51.

TOOR, R.K. and G.P. SAVAGE, 2006. Changes in major antioxidant components of tomatoes during postharvest storage. F ood Chemistry, 99: 724-727.

Vicente, A.R.; C. Pineda; L. Lemoine; P.M. Civello; G.A. Martinez and A.R. Chaves, 2005. UV-C treatments reduce decay, retain quality and alleviate chilling injury in pepper. Postharvest Biology and Technology, 35: 69-78.

W ATADA, A.E. and L. QI, 1999. Quality of fresh-cut produce. P ostharvest Biology and Technology, 15: 201205. 